\title{
Side effects of fungicides and insecticides on entomopathogenic fungi in vitro
}

\author{
Żaneta Fiedler*, Danuta Sosnowska \\ Institute of Plant Protection - National Research Institute, Władysława Węgorka 20, 60-318 Poznań, Poland
}

Vol. 57, No. 4: 355-360, 2017

DOI: 10.1515/jppr-2017-0048

Received: July 26, 2017

Accepted: October 6, 2017

Corresponding address:

Z.Fiedler@iorbip.poznan.pl

D.Sosnowska@iorbip.poznan.pl

\begin{abstract}
Products based on different strains of entomopathogenic fungi are now being used in Integrated Pest Management (IPM) programs. Compatibility studies of chemical and biological control agents are necessary to be able to give proper recommendations for their integrated use. The effect of three insecticides based on imidacloprid, spinosad and abamectin, and three fungicides based on chlorothalonil, azoxystrobin and thiophanate-methyl on the activity of the following entomopathogenic fungi: Metarhizium anisopliae (Metschn.) sensu lato, Beauveria bassiana (Bals.-Criv.) Vuill., Acremonium sp. was tested under laboratory conditions. Tests of the influence of the pesticides on growth and production of conidia were performed. From this study, we concluded that all tested insecticides can be applied together with fungus $B$. bassiana products in IPM programs. They even stimulate sporulation of this fungus at the recommended dose, 0.5 of the recommended dose and 1.5 times the recommended dose. In the case of fungicides we observed inhibition of growth and sporulation of B. bassiana and reduction of growth and sporulation of other species of fungi.
\end{abstract}

Key words: colony growth, entomopathogenic fungi, in vitro, side effects of pesticides, sporulation

\section{Introduction}

Parasitic fungi which significantly reduce populations of plant pests under natural conditions play an important role in the biological control of pests. Their effectiveness, however, very much depends on the environmental conditions, particularly, temperature and humidity. Their use in practice often does not give expected results, especially under field conditions. Most often, they are used to control the number of pests of greenhouse crops where the situation is more favourable due to the possibility of adjusting both the temperature and humidity (Sosnowska 2013).

Entomopathogenic fungi are an important biological factor used to control many species of plant pests. Of 100,000 fungi species, approximately 1,200 species are described as insect pathogens. Of these, seven species are used to control plant pest insects in augmentative biological control (van Lenteren et al. 2017). Currently, biological control agents that are commercially available are based mainly on entomophagous species (van Lenteren 2003). Nevertheless, there is a constant search for other types of biological control agents, including pathogenic fungi.

Directive 2009/128/EC of the European Parliament and the Council established a framework for the European Community to achieve sustainable use of pesticides (Directive 2009). Article 14 of this Directive says that member states shall take all necessary measures to promote low pesticide input pest management, giving wherever possible priority to non-chemical methods. From January 1st, 2014 professional users of pesticides should switch to practices and products with the lowest risk to human health and the environment. Biological control agents can play an important role in Integrated Pest Management (IPM), which does not necessarily need highly selective products but products that do not disrupt natural control, do not promote pest 
outbreak after treatments or secondary pests previously controlled. It is important to know the side effects of pesticides on beneficial organisms for IPM. It is known that pesticides can have different effects on growth, sporulation and pathogenicity of entomopathogenic fungi (Majchrowicz and Poprawski 1993; Tkaczuk 2001; Rashid et al. 2010; Hernandez et al. 2012; Tkaczuk et.al. 2012, 2015; Pelizza et al. 2015). The obtained data may be helpful in the development of IPM strategies using beneficial control agents like microorganisms with chemical pesticides.

The main objective of the research presented in this paper was to evaluate the side effects of selected fungicides and insecticides on the growth and sporulation of entomopathogenic fungi: Beauveria bassiana (Bals.-Criv.) Vuill., Metarhizium anisopliae (Metschn.) sensu lato (s.1.) and Acremonium sp. (previously known as Cephalosporium).

\section{Materials and Methods}

\section{Fungal isolates}

Experiments were carried out under laboratory conditions. Three Polish isolates of entomopathogenic fungi were taken from the colletion of the Department of Biological Pest Control, Institute of Plant Protection - National Research Institute, Poznań, Poland. The B. bassiana and M. anisopliae s.l. strains were isolated from insects which occur in the litter in the Białowieża Forest. Acremonium sp. was isolated from greenhouse whitefly (Trialeurodes vaporariorum).

The fungal isolates were cultured on potato dextrose agar (PDA) medium and plates were incubated in a growth chamber in the dark at $25^{\circ} \mathrm{C}$ for 10 days. Fungi were assigned to a species according to their morphological features (Hodge 2000).

\section{Preparation of media with pesticides}

The PDA medium was sterilized in an autoclave at $121^{\circ} \mathrm{C}$ for $15 \mathrm{~min}$. When the medium reached $50-60^{\circ} \mathrm{C}$ precisely measured doses of pesticides were added. Subsequent concentrations of pesticides in medium were obtained by dilution. Three insecticides were used: Confidor 200 SL (imidacloprid), Biospin 120 SC (spinosad) and Vertimec 018 EC (abamectin), and three fungicides: Amistar 250 SC (azoxystrobin), Bravo 500 SC (chlorothalonil), Topsin 200 SL (thiophanate-methyl) at three concentrations. The tested pesticides were added to the medium at the following doses: $\mathrm{B}$ - 0.5 recommended dose, $\mathrm{C}$ - recommended dose, D - 1.5 recommended dose, A - control, fungi cultures grown on medium without pesticides.

\section{Estimation of daily fungal colony growth and sporulation}

Agar plugs ( $0.8 \mathrm{~cm}$ diameter) with different fungi species were placed in the middle of $9 \mathrm{~cm}$ diam. Petri dishes containing PDA medium with fungicides or insecticides at different concentrations with fungi plugs. Then Petri dishes were placed in an incubator at $25^{\circ} \mathrm{C}$. Colony growth was observed every day until the 7th day of culturing by measuring the colony diameter (in $\mathrm{mm}$ ). The results are presented as colony daily linear growth $(\mathrm{cm})$ as an average of each day's colony growth. Each treatment was performed in four replications.

Sporulation of the fungi colonies was assessed on the 7th day. The conidial suspension was prepared in a homogenizer by grinding the whole fungi colonies in $10 \mathrm{ml}$ of sterile water. The number of spores $/ 1 \mathrm{~cm}^{2}$ of the colony surface was estimated using a haemocytometer.

According to the scale proposed by Alves et al. (1998) the toxic impact of chemical substances on the development of fungi was determined with the following equation:

$$
\mathrm{T}=20(\mathrm{VG})+80(\mathrm{SP}) / 100,
$$

where: VG - mycelium growth, SP - sporification.

The following scale was devised: 0-30 - very toxic, 31-45 - toxic, 46-60 - moderate toxicity, above $60 \%$ - low toxicity.

\section{Statistical analysis}

The obtained results were subject to a random ANOVA variance analysis. The significance of the observed differences was tested with the use of data transformed to angular degrees or non-transformed data, according to the Freeman-Tukey test with the level of significance $\mathrm{p}<0.001$.

\section{Results}

The results showed a significant difference in terms of susceptibility of the used fungi species in relation to the examined fungicides and insecticides (Table 1).

The addition of the insecticides to the culture medium at the recommended dose, at 0.5 of the recommended dose and at 1.5 times the recommended dose inhibited the growth of $M$. anisopliae s.l. colony (Fig. 1). The greatest number of spores was observed with 0.5 of the recommended dose of insecticide Vertimec $018 \mathrm{EC}$. The number of spores in $1 \mathrm{~cm}^{2}$ of the colony was even higher $\left(2.85 \times 10^{7}\right)$ than in the control $\left(1.2 \times 10^{7}\right)$ and differed significantly from the control 
Table 1. Daily linear growth of fungi isolates on media with insecticides on the 7th day of observation

\begin{tabular}{lccc}
\hline \multicolumn{1}{c}{ Treatment } & \multicolumn{3}{c}{ Daily linear growth [cm] } \\
\cline { 2 - 4 } & Beauveria bassiana & Metarhizium anisopliae s.l. & Acremonium sp. \\
\hline 1a-Confidor 200 SL (1) & $0.48 \pm 0.2 \mathrm{ab}$ & $0.27 \pm 0.09 \mathrm{bc}$ & $0.32 \pm 0.08 \mathrm{bc}$ \\
1b-Confidor 200 SL (0.5) & $0.5 \pm 0.1 \mathrm{~b}$ & $0.36 \pm 0.06 \mathrm{c}$ & $0.41 \pm 0.06 \mathrm{~b}$ \\
1c-Confidor 200 SL (1.5) & $0.45 \pm 0.1 \mathrm{ab}$ & $0.29 \pm 0.1 \mathrm{bc}$ & $0.30 \pm 0.1 \mathrm{bc}$ \\
2a-Biospin 120 SC (1) & $0.35 \pm 0.04 \mathrm{a}$ & $0.31 \pm 0.0 \mathrm{c}$ & $0.15 \pm 0.02 \mathrm{a}$ \\
2b-Biospin 120 SC (0.5) & $0.4 \pm 0.1 \mathrm{a}$ & $0.33 \pm 0.1 \mathrm{c}$ & $0.32 \pm 0.1 \mathrm{~b}$ \\
2c-Biospin 120 SC (1.5) & $0.38 \pm 0.08 \mathrm{a}$ & $0.3 \pm 0.1 \mathrm{c}$ & $0.27 \pm 0.1 \mathrm{~b}$ \\
3a-Vertimec 018 EC (1) & $0.36 \pm 0.0 \mathrm{a}$ & $0.23 \pm 0.1 \mathrm{bc}$ & $0.25 \pm 0.1 \mathrm{~b}$ \\
3b-Vertimec 018 EC (0.5) & $0.45 \pm 0.01 \mathrm{ab}$ & $0.24 \pm 0.06 \mathrm{bc}$ & $0.52 \pm 0.1 \mathrm{c}$ \\
3c-Vertimec 018 EC (1.5) & $0.43 \pm 0.2 \mathrm{a}$ & $0.14 \pm 0.0 \mathrm{a}$ & $0.28 \pm 0.08 \mathrm{~b}$ \\
Control & $0.34 \pm 0.09 \mathrm{a}$ & $0.44 \pm 0.2 \mathrm{~cd}$ & $0.6 \pm 0.09 \mathrm{~d}$ \\
\hline
\end{tabular}

Mean number \pm standard deviation calculated from four replications, means followed by the same letter in each column are not significantly different $(p<0.001),(1)$ - recommended dose, (0.5) - half of the recommended dose, (1.5) - one and a half times the recommended dose

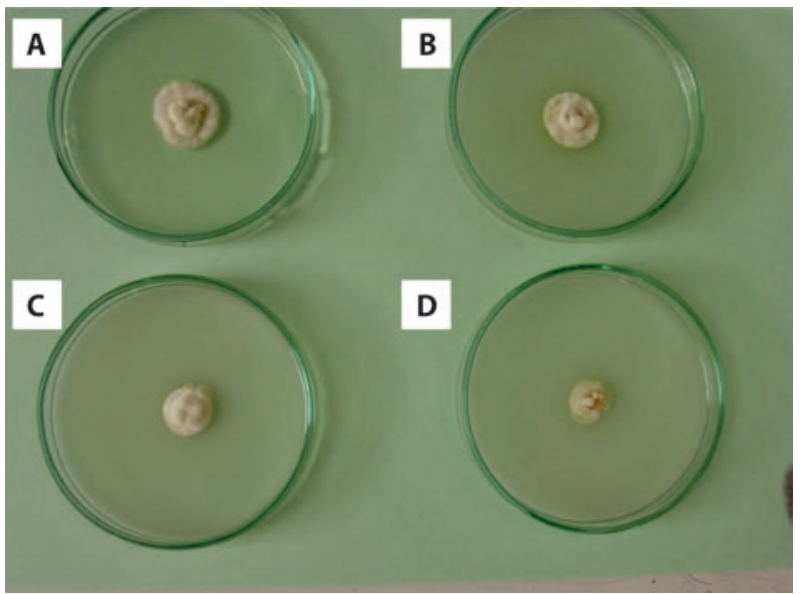

Fig. 1. Growth of 7-day old colonies of Metarhizium anisopliae s.l. on media with Biospin 120 SC. A - control, B - 0.5 of the recommended dose, $C-1$ of the recommended dose, $D-1.5$ of the recommended dose and other treatments, indicating that the insecticide stimulates M. anisopliae s.l. sporulation (Table 2). Confidor 200 SL and Biospin 120 SC reduced growth and sporulation of this fungus. The study showed that among the tested insecticides Confidor 200 SL had the greatest inhibitory effect on the sporulation of M. anisopliae s.l. When used at the recommended dose and at 1.5 times the recommended dose it caused complete inhibition of fungus sporulation (Table 2). Half of the recommended dose of Cofidor $200 \mathrm{SL}$ also inhibited the sporulation of $M$. anisopliae, but its influence was significantly weaker than the other doses used.

The Acremonium sp. strain was the most susceptible to all of the examined insecticides. All tested concentrations of the insecticides reduced the production of spores in comparison with the control (Table 2).

Table 2. Number of spores on media with insecticides on the 7th day of observation

\begin{tabular}{lccc}
\hline \multirow{2}{*}{ Treatment } & \multicolumn{3}{c}{ Number of spores per $1 \mathrm{~cm}^{2}$ of the colony $\times 10^{7}$} \\
\cline { 2 - 4 } & Beauveria bassiana & Metarhizium anisopliae s.l. & Acremonium sp. \\
\hline 1a-Confidor 200 SL (1) & $114.2 \pm 28 \mathrm{~b}$ & $0 \pm 0.0 \mathrm{a}$ & $38.5 \pm 4 \mathrm{bc}$ \\
1b-Confidor 200 SL (0.5) & $107.8 \pm 12 \mathrm{~b}$ & $0.11 \pm 0.01 \mathrm{~b}$ & $43.4 \pm 8 \mathrm{c}$ \\
1c-Confidor 200 SL (1.5) & $126.3 \pm 34 \mathrm{c}$ & $0 \pm 0.0 \mathrm{a}$ & $34.8 \pm 12 \mathrm{bc}$ \\
2a-Biospin 120 SC (1) & $157 \pm 26 \mathrm{~d}$ & $0.19 \pm 0.11 \mathrm{~b}$ & $28.7 \pm 4 \mathrm{~b}$ \\
2b-Biospin 120 SC (0.5) & $105 \pm 22 \mathrm{~b}$ & $0.33 \pm 0.08 \mathrm{c}$ & $40.9 \pm 12 \mathrm{c}$ \\
2c-Biospin 120 SC (1.5) & $177 \pm 34 \mathrm{~d}$ & $0.06 \pm 0.01 \mathrm{ab}$ & $29.4 \pm 8 \mathrm{~b}$ \\
3a-Vertimec 018 EC (1) & $167.8 \pm 54 \mathrm{~d}$ & $1.13 \pm 0.1 \mathrm{~d}$ & $34.4 \pm 21 \mathrm{bc}$ \\
3b-Vertimec 018 SC (0.5) & $265.7 \pm 48 \mathrm{e}$ & $2.85 \pm 0.2 \mathrm{e}$ & $32.8 \pm 9 \mathrm{bc}$ \\
3c-Vertimec 018 SC (1.5) & $187.3 \pm 32 \mathrm{~d}$ & $0.44 \pm 0.06 \mathrm{c}$ & $22.8 \pm 4 \mathrm{ab}$ \\
Control & $54.9 \pm 12 \mathrm{a}$ & $1.2 \pm 0.1 \mathrm{~d}$ & $52.2 \pm 4 \mathrm{~d}$ \\
\hline
\end{tabular}

Mean number \pm standard deviation calculated from four replications, means followed by the same letter in each column are not significantly different $(p<0.001),(1)$ - recommended dose, $(0.5)$ - half of the recommended dose, (1.5) - one and a half times the recommended dose 


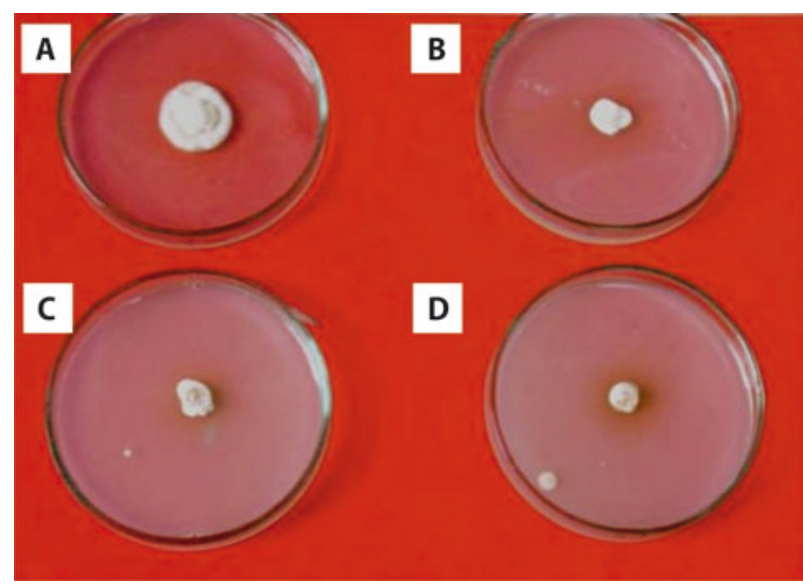

Fig. 2. Growth of 7-day-old colonies of Acremonium sp. on media with Confidor $200 \mathrm{SL}$. A - control, B - 0.5 of the recommended dose, $\mathrm{C}-1$ of the recommended dose, $\mathrm{D}-1.5$ of the recommended dose

The greatest daily growth of the colony of this fungus $(0.6 \mathrm{~cm})$ was observed in the control where no insecticides were used. This value significantly differed from other treatments (Table 1, Fig. 2). A similar situation was observed during the production of spores $\left(52.2 \times 10^{7}\right.$ per $1 \mathrm{~cm}^{2}$ of the colony) in the control and also significantly differed from the treatments with the addition of insecticides to the culture medium. No stimulating activity of the insecticides on the growth of the colony and the production of spores of Acremonium sp. was observed.

The B. bassiana fungus was less sensitive to the used insecticides where daily growth of the colony was greater than the control for all concentrations (Fig. 3). The largest number of spores in comparison with the control in all treatments was also observed and in all cases the difference was highly significant. The greatest number of spores was observed with the use of the

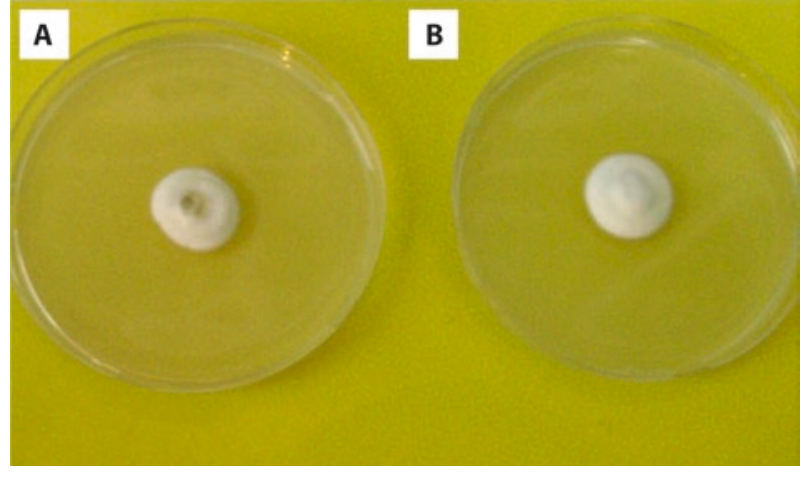

Fig. 3. Growth of 7-day-old colonies of Beauveria bassiana on media with Confidor 200 SL. A - control, B - 1.5 of the recommended dose

recommended dose, 0.5 and 1.5 times the recommended dose of Vertimec 018 EC (abamectin) (Table 2). The number of spores per $1 \mathrm{~cm}^{2}$ was almost threetimes higher than in the control (Table 2). This indicates the stimulating activity of the insecticides used on this fungus strain.

By adding three fungicides which are most frequently used in the control of greenhouse crops, it was observed that all fungicides used demonstrated fungistatic activity against the entomopathogenic fungi, where the most susceptible strain appeared to be the B. bassiana (Tables 3, 4).

All used fungicides demonstrated fungicidal activity against $B$. bassiana. No production of spores was observed in any of the concentrations, whereas in the control the number of spores reached $65 \times 10^{9} /$ colony (Table 4). A certain growth of fungi colony was observed after adding the fungicides to the culture medium in all treatments - from $0.1 \mathrm{~cm}$ to $0.2 \mathrm{~cm}$, but it differed significantly from the control where the growth was $0.4 \mathrm{~cm} \cdot$ day $^{-1}$ (Table 3 ).

Table 3. Daily linear growth of fungi isolates on media with fungicides on the 7 th day of observation

\begin{tabular}{lccc}
\hline \multirow{2}{*}{ Treatment } & \multicolumn{3}{c}{ Daily linear growth [cm] } \\
\cline { 2 - 3 } & Beauveria bassiana & Metarhizium anisopliae s.l. & Acremonium sp. \\
\hline 1a-Topsin 200 SL (1) & $0.1 \pm 0.08 \mathrm{a}$ & $0.2 \pm 0.02 \mathrm{~b}$ & $0.1 \pm 0.04 \mathrm{a}$ \\
1b-Topsin 200 SL (0.5) & $0.2 \pm 0.02 \mathrm{~b}$ & $0.3 \pm 0.06 \mathrm{bc}$ & $0.2 \pm 0.02 \mathrm{~b}$ \\
1c-Topsin 200 SL (1.5) & $0.1 \pm 0.02 \mathrm{a}$ & $0.1 \pm 0.02 \mathrm{a}$ & $0.08 \pm 0.02 \mathrm{a}$ \\
2a-Amistar 250 SC (1) & $0.1 \pm 0.02 \mathrm{a}$ & $0.1 \pm 0.02 \mathrm{a}$ & $0.2 \pm 0.06 \mathrm{~b}$ \\
2b-Amistar 250 SC (0.5) & $0.1 \pm 0.01 \mathrm{a}$ & $0.2 \pm 0.01 \mathrm{~b}$ & $0.1 \pm 0.06 \mathrm{a}$ \\
2c-Amistar 250 SC (1.5) & $0.1 \pm 0.02 \mathrm{a}$ & $0.08 \pm 0.02 \mathrm{a}$ & $0.2 \pm 0.02 \mathrm{~b}$ \\
3a-Bravo 500 SC (1) & $0.1 \pm 0.06 \mathrm{a}$ & $0.3 \pm 0.06 \mathrm{bc}$ & $0.06 \pm 0.02 \mathrm{a}$ \\
3b-Bravo 500 SC (0.5) & $0.2 \pm 0.08 \mathrm{~b}$ & $0.3 \pm 0.08 \mathrm{bc}$ & $0.3 \mathrm{~b} \pm 0.04 \mathrm{bc}$ \\
3c-Bravo 500 SC (1.5) & $0.1 \pm 0.08 \mathrm{a}$ & $0.3 \pm 0.02 \mathrm{bc}$ & $0.1 \pm 0.06 \mathrm{a}$ \\
Control & $0.4 \pm 0.1 \mathrm{c}$ & $0.4 \pm 0.08 \mathrm{c}$ & $0.4 \pm 0.1 \mathrm{c}$ \\
\hline
\end{tabular}

Mean number \pm standard deviation calculated from four replications, means followed by the same letter in each column are not significantly different $(p<0.001),(1)$ - recommended dose, (0.5) - half of the recommended dose, (1.5) - one and a half times of the recommended dose 
Table 4. Number of spores on media with fungicides on the 7th day of observation

\begin{tabular}{lccc}
\hline \multirow{2}{*}{ Treatment } & \multicolumn{3}{c}{ Number of spores per $1 \mathrm{~cm}^{2}$ of the colony $\times 10^{7}$} \\
\cline { 2 - 4 } & Beauveria bassiana & Metarhizium anisopliae s.l. & Acremonium sp. \\
\hline 1a-Topsin 200 SL (1) & $0 \pm 0.0 \mathrm{a}$ & $2 \pm 0.8 \mathrm{~b}$ & $20.1 \pm 2 \mathrm{~b}$ \\
1b-Topsin 200 SL (0.5) & $0 \pm 0.0 \mathrm{a}$ & $2 \pm 0.4 \mathrm{~b}$ & $52.8 \pm 6 \mathrm{c}$ \\
1c-Topsin 200 SL (1.5) & $0 \pm 0.0 \mathrm{a}$ & $0 \pm 0.0 \mathrm{a}$ & $10.5 \pm 2 \mathrm{a}$ \\
2a-Amistar 250 SC (1) & $0 \pm 0.0 \mathrm{a}$ & $3.7 \pm 0.8 \mathrm{bc}$ & $22.3 \pm 4 \mathrm{~b}$ \\
2b-Amistar 250 SC (0.5) & $0 \pm 0.0 \mathrm{a}$ & $4.3 \pm 1.1 \mathrm{bc}$ & $28.3 \pm 4 \mathrm{~b}$ \\
2c-Amistar 250 SC (1.5) & $0 \pm 0.0 \mathrm{a}$ & $2.3 \pm 0.6 \mathrm{~b}$ & $14.8 \pm 6 \mathrm{a}$ \\
3a-Bravo 500 SC (1) & $0 \pm 0.0 \mathrm{a}$ & $2.5 \pm 0.4 \mathrm{~b}$ & $14.8 \pm 12 \mathrm{a}$ \\
3b-Bravo 500 SC (0.5) & $0 \pm 0.0 \mathrm{a}$ & $5.3 \pm 1.2 \mathrm{c}$ & $26.3 \pm 6 \mathrm{~b}$ \\
3c-Bravo 500 SC (1.5) & $0 \pm 0.0 \mathrm{a}$ & $1.5 \pm 0.4 \mathrm{~b}$ & $38.5 \pm 8 \mathrm{~b}$ \\
Control & $65 \pm 15.6 \mathrm{~b}$ & $15.8 \pm 3.2 \mathrm{~d}$ & $190 \pm 21 \mathrm{~d}$ \\
\hline
\end{tabular}

Mean number \pm standard deviation calculated from four replications, means followed by the same letter in each column are not significantly different $(p<0.001),(1)$ - recommended dose, $(0.5)$ - half of the recommended dose, (1.5) - one and a half times the recommended dose

All fungicides reduced daily mycelium growth and the number of spores per $1 \mathrm{~cm}^{2}$ of the colony of Acremonium sp. (Tables 3, 4). The fungus M. anisopliae s.l. was also susceptible to all used fungicides. They reduced mycelium growth and sporulation of this fungus.

\section{Discussion}

Compatibility of chemical pesticides with microorganisms needs to be investigated, especially when they are and will be part of IPM programs. It is important to know the side effects of pesticides on beneficial organisms such as entomopathogenic fungi. Insecticides are generally less harmful to entomopathogens due to their mode of action. All tested insecticides added to the culture medium had an effect on the entomopathogenic fungi. The insecticides based on imidacloprid and spinosad applied at the recommended field dose, 0.5 of the recommended dose and 1.5 times the recommended dose showed low toxicity to the B. bassiana fungus. We even observed a stimulating effect on the growth and sporulation of this fungus. Similar results were obtained by Tkaczuk et al. (2016) when spinosad was applied at the recommended field dose. Some studies indicate synergetic effects of entomopathogenic fungi and particular insecticide substances (Pelizza et al. 2015). These researchers evaluated the efficacy of various combinations of three insecticides (luphenuron, methoxyfenozid, rynaxypar) and strains of B. bassiana and $M$. anisopliae in the control of the grasshopper pest and found that combinations of these insecticides with the tested fungi caused higher mortality of nymphs than any of the individual agents used alone. Other studies have shown that insecticides with fungi can inhibit the formation of chitin in mite cuticle and facilitate the fungi penetration inside (Hernandez et al. 2012).

In our experiment spinosad reduced the growth of M. anisopliae s.l. However, at 0.5 of the recommended dose we observed a stimulating effect on the sporulation of this fungus. A relatively small effect of insecticides on the growth and germination of entomopathogenic fungi compared to fungicides and herbicides has been observed (Miętkiewski et al. 1997; Tkaczuk et al. 2013). Other studies have shown that insecticides: fipronil, pyriproxyfen and hexaflumurion, significantly reduced the conidial germination of M. anisopliae under laboratory conditions (Rashid et al. 2010).

The insecticide based on imidacloprid stimulated growth and sporulation of $B$. bassiana, but inhibited sporulation of M. anisopliae s.l. species. Patil (2006) also observed that imidacloprid stimulated both the growth of the mycelium and sporulation of B. bassiana and $M$. anisopliae. Different results relative to $M$. anisopliae are proof that different strains of the same species of fungus react differently. They must always be investigated before the development of a strategy of Integrated Pest Control. Other biological control agents may be used in IPM, for example predatory mites. Previous studies have shown that insecticides based on abamectin and spinosad were safe to the predators, but when based on imidacloprid they were highly toxic to the predatory mites (Fiedler and Sosnowska 2014). Other studies have shown that an insecticide based on acetamiprid can be used together with $B$. bassiana and M. anisopliae (Fiedler and Sosnowska 2007). Pelizza et al. (2015) observed that insecticides tested: luphenuron, methoxyfenozide and rynaxypyr, did not affect fungi species Beauveria bassiana and M. anisopliae.

The fungus Acremonium sp. was susceptible to all tested insecticides. 
Beauveria bassiana was the most susceptible fungus to the presence of the tested fungicides. We did not observe spore production. Tkaczuk et al. (2016) reported that fungicides used in organic farming based on an extract of tea tree and copper oxychloride most strongly inhibited the growth of B. bassiana. In previous studies we have observed that $B$. bassiana was sensitive to fungicide based on propamocarb (Fiedler and Sosnowska 2011). We did not observe any sporulation of this fungus on medium with different doses of this fungicide. Metarhizium anisopliae was less susceptible to this fungicide, but Isaria $f u$ mosorosea was susceptible.

In our experiments M. anisopliae s.l. and Acremonium sp. were less susceptible to the fungicides tested. We observed growth and sporulation of these fungi on media with fungicides based on oxystrobin, chlorothalonil and thiophanate-methyl. But growth and sporulation of this fungi was significantly less than the control treatment. With 1.5 times the recommended dose fungicide Topsin 200 SL strongly inhibited the growth and sporulation of M. anisopliae s.l.

The results obtained in these studies showed that there is a constant need to conduct more research with biological control agents and chemical plant protection products. According to IPM, we should reduce the use of pesticides and apply different methods of pest control. Biological control is one opportunity for this strategy. Part of this method includes entomopathogenic fungi. In this publication, we showed that $B$. bassiana fungus can be taken into consideration as a biological control agent, which can be used together with insecticides, but not with fungicides. Metarhizium anisopliae s.l. and Acremonium sp. are more resistant to insecticides and fungicides and can be recommended as promising factors for use in IPM.

\section{References}

Alves S.B., Moino J.A., Almeida J.E.M. 1998. Produtos fitossanitarios e entomopatogenos. p. 217-238. Controle Mikrobiana de Insetos (Alves ed.). Sao Paulo, 1163 pp. (in Spanish)

Fiedler Ż., Sosnowska D. 2007. Side effects of insecticides on entomopathogenic fungi. p. 227-231. In: "Biological methods in integrated plant protection and production". Information Bulletin EPRS/IOBC, 36, Poznań-Pushkino.

Fiedler Ż., Sosnowska D. 2011. Wpływ wybranych fungicydów na wzrost i zarodnikowanie grzybów owadobójczych [The influence of fungicides on the growth and sporulation of entomopathogenic fungi]. Progress in Plant Protection 51 (2): 911-915. (in Polish)

Fiedler Ż., Sosnowska D. 2014. Side effects of fungicides and insecticides on predatory mites in laboratory conditions. Journal of Plant Protection Research 54 (4): 349-353. DOI: https://doi.org/10.2478/jppr-2014-0052

Hernandez M.M., Martinez-Villar E., Peace C., Perez-Moreno I., Marco V. 2012. Compatibility of the entomopathogenic fungus Beauveria bassiana with flufenoxuron and azadirachtin against Tetranychus urticae. Experimental and Applied
Acarology 58 (4): 395-405. DOI: https://doi.org/10.1007/ s10493-012-9594-1

Hodge A. 2000. Microbial ecology to the arbuscular mycorrhiza. FEMS Microbiology Ecology 32 (2): 91-96. DOI: https://doi.org/10.1111/j.1574-6941.2000.tb00702.x

Majchrowicz I., Poprawski T.J. 1993. Effects in vitro on nine fungicides on growth of entomopathogenic fungi. Biocontrol Science and Technology 3 (3): 321-336. DOI: https://doi. org/10.1080/09583159309355287

Miętkiewski R.T., Pell J.K., Clark S.J. 1997. Influence of pesticides use on the natural occurrence of entomopathogenic fungi in arable soils in the UK. Field and laboratory comparisons. Biocontrol Science and Technology 7 (4): 565-575. DOI: https://doi.org/10.1080/09583159730622

Patil S.B. 2006. Isolation, identification and formulation of entomopathogenic fungi and its compatibility studies with paraqat (herbicide) and other chemical pesticides with special reference to western maharashtra. Dissertation Submitted to University of Pune, p. 146.

Pelizza S.A., Scorsetti A.C., Fogel M.N., Pacheco-Marino S.G., Stenglein S.A., Cabello M.N., Lange C.E. 2015. Compatibility between entomopathogenic fungi and biorational insecticides in toxicity against Ronderosia bergi under laboratory conditions. BioControl 60 (1): 81-91. DOI: https://doi. org/10.1007/s10526-014-9606-7

Rashid M., Baghdadi A., Sheikhi A., Pourian H-R., Gazavi M. 2010. Compatibility of Metarhizium anisopliae (Ascomycota: Hypocreales) with several insecticides. Journal of Plant Protection Research 50 (1): 22-27. DOI: https://doi. org/10.2478/v10045-010-0004-6

Sosnowska D. 2013. Postępy w badaniach i wykorzystanie grzybów pasożytniczych w integrowanej ochronie roślin [Postępy w badaniach i wykorzystanie grzybów pasożytniczych w integrowanej ochronie roślin]. Progress in Plant Protection 53 (4): 747-750. DOI: https://doi.org/10.14199/ppp-2013-018 (in Polish)

Tkaczuk C. 2001. Wpływ wybranych pestycydów stosowanych w ochronie sadów na wzrost grzybów owadobójczych. Biuletyn Naukowy 12: 375-383. (in Polish)

Tkaczuk C., Majchrowska-Safaryan A., Zawadzka M. 2013. The effect of spinosad and selected synthetic insecticides on the growth of entomopathogenic fungi in vitro. Journal of Research and Applications in Agricultural Engineering 58 (4): 194-197.

Tkaczuk C., Harasimiuk M., Król A., Bereś P.K. 2015. The effect of selected pesticides on the growth of entomopathogenic fungi Hirsutella nodulosa and Beauveria bassiana. Journal of Ecological Engineering 16 (3): 177-183. DOI: https://doi. org/10.12911/22998993/2952

Tkaczuk C., Krzyczkowski T., Głuszczak B., Król A. 2012. Wpływ wybranych środków ochrony roślin na wzrost kolonii i kiełkowanie zarodników owadobójczego grzyba Beauveria bassiana (Bals.) Vuill. [The influence of selected pesticides on the colony growth and conidial germination of the entomopathogenic fungus Beauveria bassiana (Bals.) Vuill]. Progress in Plant Protection 52 (4): 969-974. (in Polish)

Tkaczuk C., Majchrowska-Safaryan A., Głuszczak B. 2016. The effect of selected pesticides approved for use in organic farming on the growth of entomopathogenic fungi [Wpływ wybranych środków ochrony roślin dopuszczonych do stosowania w uprawach ekologicznych na wzrost grzybów owadobójczych]. Progress in Plant Protection 56 (3): 265-271. DOI: http://dx.doi.org/10.14199/ppp-2016-044 (in Polish)

van Lenteren J.C. 2003. Commercial availability of biological control agents. Chapter 11. p. 167-179. In: "Quality Control and Production of Biological Control Agents: Theory and Testing Procedures" (J.C. van Lenteren, ed.). CABI Publishing, Wallingford, UK.

van Lenteren J.C., Bolckmans K., Kohl J., Ravensberg J., Urbaneja A. 2017. Biological control using invertebrates and microorganisms: plenty of new opportunities. BioControl. DOI: $10.1007 / \mathrm{s} 10526-017-9801-4$. 